\title{
CULTURAL IDENTITY, NATIONALISM AND CHANGES IN SINGING TRADITIONS
}

\section{$\underline{\text { Kristin Kuutma }}$}

In the following an attempt is made to describe some alterations in singing traditions from the aspect of sociocultural context and viewed from the Estonian perspective. As particular occasions, where singing traditions in relation to

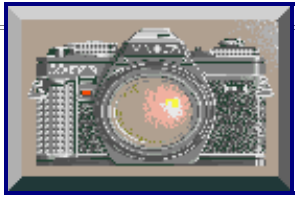
cultural identity are studied, two types of festivals have been chosen: a large national festival and a small community festival. Festival is observed here as cultural performance, charac terized by periodicity and recurrence, by impersonal and predictable movement of time (Stoeltje 1983:240). A festival provides an opportunity to study the external ori entation of customs, folkloristic phenomena, transformations in the sociocultural con text, organized performance and the functional context of singing.

I have chosen as point of departure an argument by Reimund Kvideland, that be sides considering songs as an ideal type or category, the relevant object of study should be the observable phenomenon of singing, considered as cultural expression and cultural activity. Kvideland expands the concept of folk song, and even suggests that all songs except those sung by professional singers in the role as professional performers, should be considered part of popular song tradition (Kvideland 1989:169-170).

Furthermore, Ernst Klusen introduces the expression 'group song' for what has generally been called folk song, argueing that the folk song exists in concrete form only as a group song. Folk songs have never been current among all people, but only in particular groups, sometimes of very different structure (Klusen 1986:185). Klusen defines group as a determined unit of people who interact directly, and considers song as an instrument of group life. Every age has its own song, and ev ery group has its own songs within the same time period (Klusen 1986:190). The in trigueing deductions by Klusen have been introduced in the present discourse in or der to broaden the perspective while analysing choral groups at the discussed festi vals, since organized group singing occurred both, on community level and on na tional level. Klusen discerns in group singing between primary function and second ary function. Group song in its primary function is a serving object in manifestation of community life. In its secondary function group song is experienced as a triumphant object and a spectator excperience is developed. Klusen argues that in the con temporary society the use of the song as a tool in life-shaping experiences has been replaced in many cases by a spectator experience.

\section{Festivals from the summer of 1994}

In that summer two expressive occasions of singing presented manifestations of cul tural identity, nationalism and changes in singing traditions in Estonia. On August 20, during a Setu community festival in Obinitsa village groups of women sang impro visations in the Setu tradition. On July 2-3, tens of thousands of singers gathered as choral groups for the Jubilee Song Festival in Tallinn, to celebrate the 125 year old tradition of such singing festivals.

The event in Obinitsa in the southeastern district of Estonia took place among the community of the Setu people who maintain considerable cultural and ethnic char acteristics, distinct from other parts of Estonia. These include: a local dialect which is rather different from the standard language; 
religious traditions following the Greek Catholic (here: Russian) Orthodox church, to the contrary of the prevailing Lutheran traditions in greater parts of the country; adherence to traditional customs; observ able authority of community life. The Setus have preserved their traditional singing style which is characterized by text in runoverse comparable to the syl labic-quantitative BaltoFinnic verse tradition (i.e. Kalevalaic verse metre), performed with particular polyphony and rhythm. Traditional style of performing includes the leadsinger and a two- or three-part chorus group.

During this community festival a singing competition was arranged. Though the occasion celebrated was a rather new invention - for that particular day, the Setu Kingdom was declared, an event initiated by a similar happening typical to the Finn ish community in eastern Norway, still all the elements of a traditional Setu commu nity festival were introduced. It was organized by local villagers, a church service took place on the festival eve, traditional dishes were prepared, people gathered for dance. Competition of singing is either a spontaneous or arranged event which oc curs traditionally at Setu festivals. On this occasion, the contestants were supposed to improvise songs in the traditional style on a given theme. The nine registered con testants performed as leadsingers, helped by their respective groups of singers, in cluding approximately ten women. The competition took place in the village centre, on a grassy hillside at the foot of the monument honouring a great Setu singer, Hi lana Taarka. The audience of about couple of hundred circled them, feeling free to join in with the chorus group, whose traditional task was to repeat the leadsinger's verse with required variations. (Photo 1-3)

The National Song Festival was arranged this year for the twenty-second time, exceptionally in two towns - in Tartu (southern Estonia) where the first four festivals were arranged, starting from 1869, and in the northern Tallinn, the capital city of Estonia. The recurrent occasion takes place in every fifth year. As the structure and content pattern of the festivals in Tartu and Tallinn were combined and basically coincided, it is justified to treat them as two parts of the same festival. Approximately 16000 singers drew the audience of 70000 in Tartu, and the total amount of 25000 performed for the audience of 100000 in Tallinn. In both towns the scenery was the special huge Song Festival Grounds. The bulk of singers divided among hundreds of amateur choirs who gathered from all over Estonia. The repertoire performed were choral compositions, a few of them arrangements of folk songs, and a number of authorized songs having been popular among the singers and the audience for more than a hundred years. Singing in choirs is a mass cultural activity in contemporary Estonia, and for an average Estonian the combined concepts of 'folk' and 'singing' associate with 'song festival'. (Photo 4-6)

\section{Historical and social background of singing traditions}

In the preindustrial traditional society music, including singing, formed a part of the communications system of the community and its original functional value was tied to traditional rites. Singing occurred without particular aesthetic objective and without printed text, songs were used as a means for interpreting feelings, transmitting mes sages; strengthening group identity. Musical phenomena occurring in the daily living space was rather uniform, based on the musical perception common to the particular territory and culture. The preliterate heritage of the Estonian songlore regilaul (runosong) is characterized by the Kalevalaic verse metre and the narrow ambit melody line, connected with the vernacular speech melody. The runosong is a his torical feature of the Balto-Finnic culture. The text is moulded by alliteration and syn tactic parallelism, the music by reiteration of short melody phrases. Traditionally, the performance of runosongs was largely exercised in groups, occurring in the context of communal working processes, rites and festivities. 
Solo singing took place in inti mate surroundings. The performance style of runosongs includes a leadsinger and a chorus - the leadsinger performs one verse-line which is repeated by a selected or occasional chorus with an optional number of singers while using the same or a slightly deviating melody line. Thus it can be argued that the Estonian song tradition favours collective singing.

In the eighteenth century the movement of the Herrnhuter denomination, descending from the Moravian Brethren, gained ground also among the peasant Estonians, bringing along their spiritual songlore which spread beyond church walls, assisting the folklorization of a considerably different song tradition. The official Lutheran church and village schools introduced many-part choral singing of largely German origin. Alongside with religious repertoire also German folk song arrangements for choral groups were translated into Estonian, and local original compositional at tempts were made. During the nineteenth century proceeded a profound transforma tion in the music perception among the peasant folk. The instrumentation was mod ernized in accordance with the dance music disseminating from central Europe; many-part choir singing was accompanied by the introduction of brass bands to the recreational events of the village community. The symbiosis of the inherited and bor rowed vocal tradition resulted in the evolution of strophical end-rhyme songlore. This song tradition pertained already to literate culture, the texts being often fixed in writ ing by the folk who sang them. In modern academic terminology, this category is re ferred to as the newer Estonian folk song, corresponding to the European song tradi tion of the last centuries. (Photo 7)

The described cultural changes concurred with a general socioeconomic transition. The modernization of economic life was determined by prevailing literacy provided by standard education and profound social transformations - the abolition of peasant serfdom, farmers started buying back land from the German landlords. The Herrn huter ideology had advanced egalitarian attitudes and individual initiative in social life. On the other hand, the example of the local Baltic German community intro duced also to the Estonian community (both urban and rural) the musical and educa tional societies, which in their turn propagated the need to organize, and the aspira tions for identity. Foundations for creating a conscious identity had been formed.

\section{'National awakening'}

Clifford Geertz has stated in his "Interpretation of Cultures" that the once aroused desire among a population to become a recognized and respected people in the world with their own rights, cannot be quenched (Geertz 1973:237). An in crease in newspaper circulation, an expansion of universities, a reassertion of hereditary privilege, a proliferation of folklore societies are elements which determine the collective behaviour, called nationalism. "Nationalist ideologies use cultural devices to demonstrate the process of collective self-definition, to provide feelings of pride and hope connected with symbolic forms so that these can be consciously de scribed, developed and celebrated." (Geertz 1973:252)

While conveying the aspirations for cultural independence, folklore has been instru mental in the establishment of modern nations in many European countries, Estonia included. During the eighteenth and nineteenth centuries evolved sociocultural movements (including National Romanticism) which denoted a new phase in the em pirical study of culture. Johann Gottfried Herder's concept of Volkslied, en folding origins, music, language and culture, consequently associated folk song with cultural identity, and ascribed to folk music the ability to encapsulate and specify cul tural identity (Bohlman 1988:32-33). Herder has also stated that an individual could achieve fullest development as integral part of particular nation. In order to become a nation, the body of people, with the common territory, culture, language, history, need to be sufficiently conscious of its national unity 
and identity. These ideas proved to be inspirational among the intellectuals of the Baltic region as well.

The sense of national identity, the national culture model has in many cases been built upon national symbols derived from folklore, and put to use in order to serve the particular purpose. In 1857-61 in Estonia was issued the epic "Kalevipoeg" (Kalev's Son) which was inspired by the Finnish epic "Kalevala". Our historic tradition has never provided such a collection of songs. The content and heroes of "Kalevipoeg" actually originate from various legends and tales of Estonian folk tradition. The compiler of the epic, Friedrich Reinhold Kreutzwald, a renowned medical doctor and writer, composed the themes of these folk stories into runosong verse himself, adding might and beauty whenever he found it necessary. But the outcome undoubtedly served the purpose. Kalevipoeg has entered the minds of people as a national hero from true tradition, his deeds depicting the glorious and independent past of the nation. At present only few have read the whole epic, but next to every Estonian can quote certain grandilo quent verses with particular emotional effect. And in many cases the knowledge of the runoverse heritage actually covers only "Kalevipoeg".

On the other hand, the 'national awakening' movement of Estonians is closely inter twined with music phenomena and singing activities. While following the example of Baltic German Liedertafel singing societies, the urban and rural culturally ac tive intellectuals of Estonian origin initiated quite a massive movement of choral sing ing. That in turn resulted in singing festivals occurring at various localities all over Estonia, inspired by Baltic German song festivals, the first arranged in Riga in 1836. The first Estonian singing societies with performing choirs were "Revalia" from 1863, and "Estonia" from 1865. A particular impulse for Estonian intellectuals to actively promote singing in choirs among Estonians became from the Baltic German song festival arranged in Tallinn in 1857. Consequently the first na tional Estonian song festival turned out to be an essential event, taking place in June 1869 and arranged by the Estonian singing society "Vanemuine" in Tartu. At that period the coinage 'Estonian folk' was introduced to people who used to call themselves simply 'the country folk'. The chief organizer of the event, Johann Volde mar Jannsen who was a famous newspaper publisher and an active writer, had com posed words to the melody by a Finnish composer Fredrik Pacius. During the festival that song was presented to a wider public with the result of later becoming the na tional anthem of Estonia. This major event in the musical as well as cultural-political sense - where 51 choral groups and brass bands with 845 performers participated outlined the objectives of national advancement, national unity and cultural indepen dence. Here took shape the myth which has regained strength during the recent years. The myth that the aspirations for political freedom would achieve their end in the action of singing. It has been declared that Estonian people sang themselves into becoming a nation. The interchange of the inherited and the borrowed cultural elements resulted in the creation of a new version of the national culture model (Dégh 1978:43). (Photo 8)

In the 1880 s was launched the extensive collecting of traditional heritage, initiated by folklorists and carried out from the historically oriented folkloristic aspect of archiving the already transcended past, at the same time providing the nation with cultural continuity and identity. In other words, the national pride was catered through the definition, propagation, and perpetuation of ethnic values (Dégh 1978:34). In the Estonian experience, the role of folklore in promoting national identity be came again quite essential nearly a century later. By the 1960s national song festi vals had become a phenomena basically adopted by and adapted to the Soviet re gime. Though under the official conceding surface those festivals still promoted cul tural identity and national unity, the more particular nationalistic aspirations and con scious exhibition of distinctive ethnic identity became evident in the runosong revival movement. Firstly there emerged organized groups performing 
traditional peasant folklore. Gradually professional composers turned to the ancient runosong tradition, and excellent arrangements for choral groups (particularly those by Veljo Tormis) introduced those distinctively ethnic texts and music to large numbers of singers. Hence folklore again served a particular purpose in demonstrating claims for national identity and the national culture model. The song repertoire of the so-called 'singing revolution' during 'the second national awakening' in Estonia (starting from the end of the 1980s) consisted of modern musical compositions based on runosong tradi tion and of 'patriotic' choral compositions from the last century. (Photo 9)

\section{Cultural identity and singing at festivals}

In the current postindustrial context with changed social and political background, the above described singing occasions from the summer of 1994 reflect rather dis tinctly the present age in which there is a continuous desire for ethnic recognition in individuals and groups, a search for ethnic identity, and a conscious exhibition of dis tinctive ethnic traits (Dégh 1978:36).

The Setu community festival in Obinitsa was arranged with the special objective to demonstrate and experience particularly the Setu identity. The so-called Setu King dom was declared for that one day, being another attempt to display publicly the complicated social and political situation of this ethnic group on the border zone of Estonia and Russia. These problems provided also the theme for the song contest of improvisations. (Photo 10)

The national song festival is continuously the most conspicuous and massive mani festation of cultural nationalism in Estonia. Although the repertoire of the festival is rather an item of professional music, the choral singing tradition has influenced the overall music perception and oral tradition of singing. On the other hand, traditional heritage has had reciprocal effect on organized group singing. An observable impact of folklorism accompanies the festival. Here the concept of folklorism is definitely not used in derogatory sense, but as denoting observable use of folkloristic phenomena and expressive folkloristic manifestations. Folklorism is the applied folklore of yester day, where first- and second-hand traditions are often intertwined (Bausinger 1986:114). Folkloristic phenomena have become a demonstration and entertain ment. But folkloristic manifestations increase group consciousness and serve orga nizing function. It is a matter of internal consolidation and external representation and recognition (Bausinger 1986:117). (Photo 11-13)

The singers at the community festival in Obinitsa as well as at the national song festival were dressed up in historic costumes, often with the aspiration of exhibiting local identity. The singing women in Setu wore traditional dress without exception, the garments being usually inherited from relatives or made by themselves. At the song festival especially the choirs from rural regions identified themselves by being clothed in traditional peasant costumes originating from their local districts, and obvi ously in many cases the details were self-made.

Both events were spectator oriented. The organized performances of singing had been previously prepared and rehearsed. So even in the case of the Setu singing competition, the text was not improvised on the spot. Moreover, four contestants actually do not live in the region any longer, but have migrated into various towns from south to north of the country. Together with the others in their respective chorus groups they gather regularly for rehearsals alongside with their urban daily engage ments. In fact, the Setu singing tradition has also altered. The so-called newer song type has emerged, comparable to the repertoire in the rest of Estonia, though pre serving particular local characteristics. (Photo 14) 
In case of the big song festival, noteworthy from the folkloristic aspect was the frequent spontaneous singing, occurring outside the official programme. After all, with obvious plausiblity those members of the contemporary Estonian society who have inherited the inclination and talent of selfexpression through vocal music, have mostly joined choirs active in their village or town.

Being juxtaposed, those festivals reveal divergence in the communication with the audience. The Setu occasion was a manifestation of community life and identity. The relations between the singers and the audience were interactive. The song text car ried an intended message for the audience, who listened attentively and sang along. The songs functioned as transmitters of information inside the community. The audi ence identified themselves with songs - when one contestant could not hold back her tears while singing about her childhood home now inaccessible across border on the Russian side, a number of those in the audience also wiped their eyes.

The national song festival was expected to be a spectator experience. The com posed choral pieces are intended for being passively enjoyed as music composi tions. But in reality the audience seeks the opportunity to sing along. And evidently the majority of audience identifies themselves with the text of certain songs that have become national symbols. Not only these performing on stage but also those func tioning as audience, expect to experience the positive exaltation of singing the same melodies and words with thousands of others. In addition, the national song festival is for many a major social occasion which is attended by whole families, with the en deavour of meeting distant friends and relatives, as the audience as well as perform ers gather from all over the country. (Photo $\underline{15)}$

The study of those particular occasions leads to a conclusion that the functions of the festival as cultural performance are equivalent on the community level and on the national level. The festival provides a scenery for manifestations of cultural and national identity, national and ethnic unity. Complementing the transformations in so ciocultural context, the observable phenomenon of uttering political ideas and aes thetic images with musical modulations of the voice (i.e. singing) continues to be a significant mechanism, which affects social behaviour. For example, it may serve as a cultural response to the national desire for independence. One noteworthy process in Estonia has been the alteration of music perception resulting in song festival movement, which in turn has had essential impact on the modern nation-building. The environmental adaptation of the historic tradition can be observed in the versa tile expressions of cultural acitivities. In contemporary society the traditional aesthetic folklore is cultivated in organized performance groups.

\section{Reference cited}

Brednich, Rudolf Wilhelm. 1986. The Song as a Commodity. In: Ger man Volkskunde. Bloomington, Ind.

Bausinger, Hermann. 1986. Toward a Critique of Folklorism Criticism. In: German Volkskunde. Bloomington, Ind.

Bohlman, Philip V. 1988. Traditional Music and Cultural Identity: Persistent Paradigm in the History of Ethnomusicology. In: Yearbook of Traditional Mu sic.

Dégh, Linda. 1978. The Study of Ethnicity in Modern European Eth nology. In: Folklore, Nationalism and Politics. Ed. by Felix Oinas. Columbus, Ohio. 
Geertz, Clifford. 1973. The Interpretation of Cultures. New York.

Klusen, Ernst. 1986. The Group Song as Object. In: German Volkskunde. Bloomington, Ind.

Kvideland, Reimund. 1989. Folk Ballads and Folk Song. In: Nordic Folklore. Bloomington, Ind.

Leichter, Karl. 1991. Seitse sajandit eestlaste lauluteel : Kultuuriloolisi and meid aastaist 1172-

1871. (Seven Centuries of the Estonians' Path of Singing : Cul tural Data from 1172-1871) Tallinn.

Põldmäe, Rudolf. 1988. Vennastekoguduse muusikalisest tege vusest meie maal. (The Musical

Activities of the Moravian Brethren in Our Coun try) In: Teater. Muusika. Kino.

Stoeltje, Beverly J. 1983. Festival in America. In: Handbook of American Folklore. Ed. by Richard M. Dorson. Bloomington, Ind.

Wilson, William A. 1978. The "Kalevala" and Finnish Politics. In: Folklore, Nationalism and Politics. Ed. by Felix Oinas. Columbus, Ohio. 